\title{
Teachers' and Learners' Inclinations towards Animal Organ Dissection and Its Use in Problem-Solving
}

\author{
Portia Kavai \\ Dr., University of Pretoria, South Africa,portia.kavai@up.ac.za
}

Rian de Villiers

Assoc. Prof., University of Pretoria, South Africa, rian.devilliers@up.ac.za

\section{William Fraser}

Prof., University of Pretoria, South Africa, william.fraser@up.ac.za

In Life Sciences (biology) education, both nationally and internationally, the study of animal and organ morphology has traditionally involved dissection since the early $19^{\text {th }}$ century. This study focused on the inclinations of teachers and learners towards animal organ dissection, and its use in problem-solving in Grade 11 Life Sciences education in the Gauteng Province, South Africa. A mixed methods research design was used to collect data from 224 learners with a questionnaire, followed by lesson observations and interviews with six teachers. The results show that the majority of the teachers and learners had great interest in performing animal organ dissections, believing that its use could add value to the solving of specific problems that are related to the Grade 11 Life Sciences curriculum. A few teachers were not keen on animal organ dissection and were reluctant to let their learners dissect and use it in problem-solving. The few learners with reservations about animal organ dissection preferred artificial organs due to a blood phobia and squeamishness. This study supports the development of artificial animal organ dissection as a teaching strategy in support of problem-solving in teaching.

Key Words: biology, dissection, inclinations, learners, life sciences, problem-solving, teachers

\section{INTRODUCTION}

For centuries, educators in different parts of the world have used dissection in the teaching of learners, ${ }^{1}$ either by demonstration or hands-on practice, allowing learners to learn through discovery (Morton, 1987). This, however, contributed to much controversy internationally (Millet \& Lock, 1992; Reiss \& Beaney, 1992; Smith, 1994; Stannistreet, Spofforth \& Williams, 1993). These arguments result in different inclinations towards animal organ dissection from teachers and learners. Since teachers'

Citation: Kavai, P., Villiers, R. \& Fraser, W. (2017). Teachers' and Learners' Inclinations towards Animal Organ Dissection and Its Use in Problem-Solving. International Journal of Instruction, 10(2), 39-54. https://doi.org/10.12973/iji.2017.1023a 
inclinations may impact teaching outcomes and learner attitudes, there was also a need to find out the inclinations of the learners. This study therefore aimed to explore the inclinations of both the teachers and the learners towards animal organ dissection in general, and its use in problem-solving more specifically. It was deemed important to explore these inclinations as they may possibly have a direct impact on how the dissections are performed, for example, some teachers may be underutilising the use of animal organ dissections, which in turn may have an effect on the contribution of authentic animal organ dissection to the teaching of Life Sciences.

Inclinations involve a person's natural tendency; feeling in a particular way; or a person's disposition, which play a major role in organising and directing the behaviour and support for him/her to achieve his/her goal. It is the most important factor that contributes to the formation of an individual's decision on certain practices (Al-Tamimi, 2015; Osama, 2000). The inclinations of an individual, whether positive or negative, are influenced by their attitude towards a topic, activity, or related issues. This is supported by a few authors, including Mohamed and Waheed (2011), and Gbore and Daramola (2013), who consider attitude as personal feelings and predispositions that guide an individual's behavior and influence inclinations, which can be evaluated as either positive or negative. These inclinations possibly influence one's performance and activities.

Researchers and authors worldwide, including in the United States, Europe, and South Africa (Balcombe, 1997; Balcombe, 2000; De Villiers \& Sommerville, 2005; Donaldson \& Downie, 2007; Downie \& Alexander, 1989; Moore, 2001) have explored how students ${ }^{2}$ at different stages of education feel about carrying out dissection as part of the Life Sciences curriculum. The outcomes varied according to the diversity of the school environments; these environments are also very common in South Africa. A study carried out by Stanisstreet, Spofforth and Williams (1993) claims that $48 \%$ of secondary school learners thought animal dissection to be wrong. Lord and Moses (1994) found that almost half (48\%) of the participants in their study objected to the idea of dissecting a rabbit, whilst the majority of the students $(80 \%)$ did not object to the dissection of preserved animals. Donaldson and Downie (2007) report that university students recognise the educational value of animal uses, but disapprove of the killing of animals for this purpose. De Villiers and Sommerville (2005) involved a sample of Life Sciences student teachers in South Africa to assess their attitudes towards dissection. They found that $71 \%$ of the students expected their learners to do dissection, showing a more positive inclination towards dissection. In many cases, Life Sciences teachers are expected to use animal and organ dissection in their classrooms, regardless of the teacher's personal preference or teaching method. These practices, according to King, Ross, Stephens, and Rowan (2004), are widespread.

Problem-solving, as one of the high-order learning skills, is one of the skills that Life Sciences learners should acquire according to the National Curriculum Statement (NCS) of the Department of Basic Education (DBE) in South Africa. The dissection of animal organs as a curriculum requirement may be used to help learners to develop skills, including investigation, inquiry, and problem-solving. One could therefore argue that animal organ dissections could be a valuable approach to creating authentic 
'communities of inquiry' (Garrison, 2007). The problems given by the teachers during the dissection of animal organs provide a context that helps learners later to remember the specific content they encountered while solving them (McCain, 2005). Life Sciences teachers may also take the problem-solving models into consideration during dissection lessons so that learners may acquire more skills than just cutting, drawing, and labelling. Nevertheless, learners should be emotionally prepared for the engagement.

\section{Conceptual framework}

Following the literature review, the researchers summarised the concepts relevant to this study to develop the overall conceptual framework of the study, as shown in Figure 1.

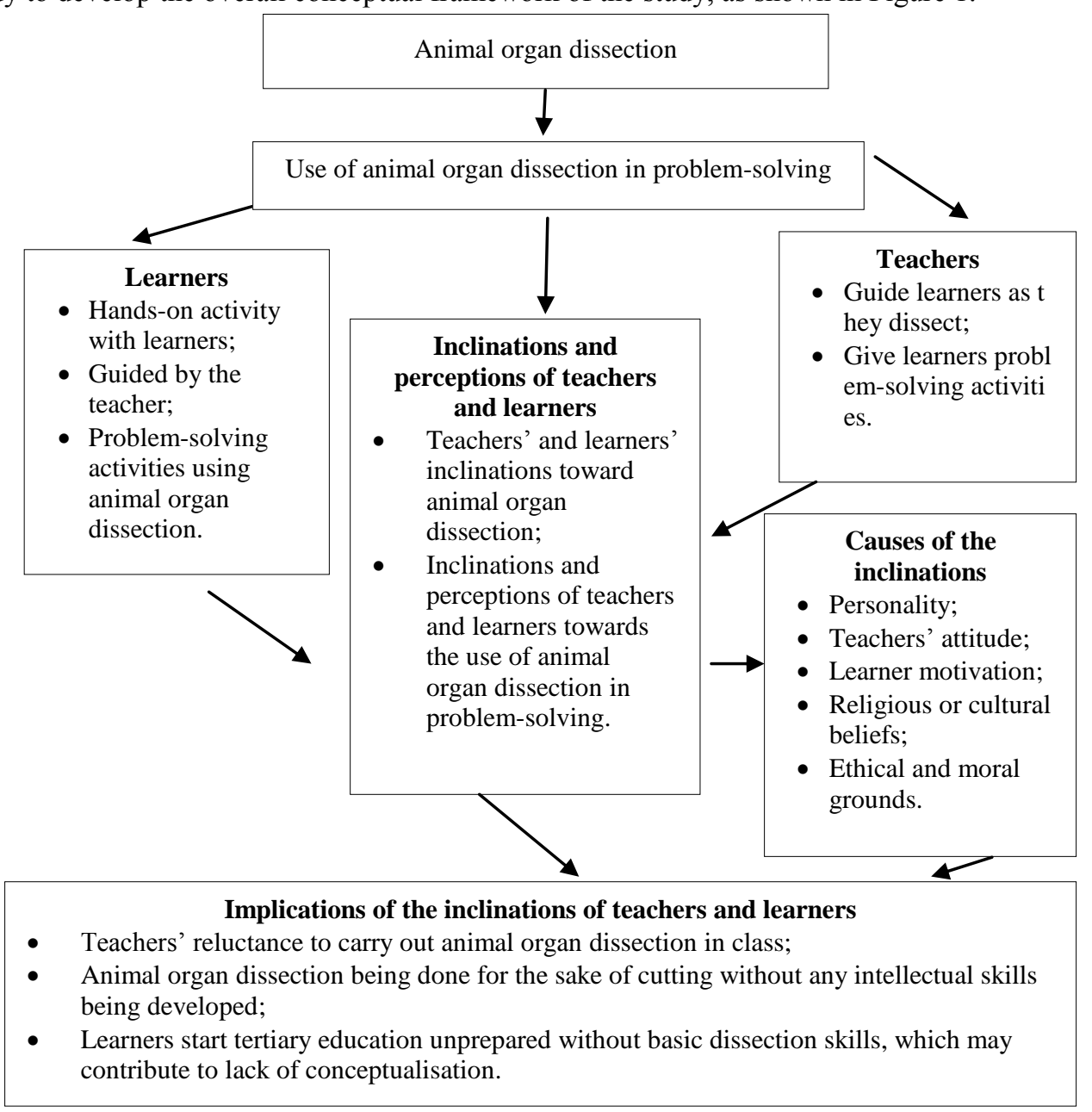

Figure 1

A diagrammatic representation of the conceptual framework for the study on inclinations towards animal organ dissection and its use in problem-solving 
Animal organ dissection carried out by the learners with the guidance of their teachers may result in some inclinations that could be positive or negative. According to the literature, the reasons for these inclinations may range from personality, ethical, moral, religious background, learner motivation to the teacher's inclinations towards this hands-on activity. Some inclinations towards the use of animal organ dissection in problem-solving and the implications of these inclinations were then established in this study since there was a dearth in literature linking animal organ dissection to problemsolving.

\section{Research questions}

The research questions that guided the research were as follows:

1. What are the teachers' and learners' inclinations towards animal organ dissection?

2. What are the teachers' and learners' inclinations towards the use of animal organ dissection in problem-solving?

3. How do the teachers' and learners' inclinations affect the use of animal organ dissection in problem-solving?

\section{METHOD}

This study was driven by a concurrent mixed methods approach. The reason for using the concurrent mixed methods approach was to ensure that both quantitative and qualitative approaches complemented one another, and also for the purposes of triangulation, expansion, and development (Creswell, 2009). This method comprised the use of a small survey $(\mathrm{n}=224)$, whilst in the qualitative sections, interviews and lesson observations formed part of the investigation.

The first phase of the study started as a content (textual) analysis through which the researchers analysed the National Curriculum Statement (NCS) and the new Continuous Assessment Policy Statements (CAPS) syllabus. The criteria for this analysis were based on problem solving and dissection. During the second qualitative phase, learners were observed while dissecting organs. The third phase followed a quantitative survey where learners completed a questionnaire to establish their experience and feelings during the dissection. Lastly, the teachers were interviewed.

\section{Sample and setting}

Two hundred and twenty-four (224) Grade 11 Life Sciences learners, and six Grade 11 Life Sciences teachers at four high schools in Pretoria, South Africa were conveniently sampled to participate in this study. Grade 11 is the second last grade of high school training. The criteria for choosing the schools were as follows: School A was a township ${ }^{3}$ public (state owned) school without any laboratory facilities and laboratory apparatus; School B was a suburban public school with laboratory facilities and laboratory apparatus; School C was an independent (privately owned) suburban school with adequate laboratory facilities and laboratory apparatus; and School D was an independent township school with limited laboratory facilities and laboratory apparatus. 


\section{Data collection instruments}

The data were collected by having 224 Grade 11 learners complete a questionnaire, and observing the lessons and interviewing the six Grade 11 Life Sciences teachers of the selected schools after the learners had carried out an animal organ dissection. According to Creswell (2009), multiple instrumentation is a valuable technique that increases the validity and reliability of a study, and ensures the triangulation of the data. The learners' questionnaire covered three parts. Section $A$ asked for biographical details, including age, gender, religion, and cultural groups. Section $B$ (closed Likert-type questions) captured the learners' opinions regarding dissection and problem-solving, and Section $C$ (open-ended questions) dealt with their feelings towards animal organ dissection. The questionnaire yielded a high Cronbach's Alpha coefficient estimation of 0.83 .

\section{Data analysis}

A descriptive analysis was applied to the responses of the questionnaire (frequency counts and percentages) (Gay \& Airasian, 2000). The qualitative data from the teacher interviews were then analysed, coded and classified (Cohen et al., 2000). To ensure anonymity, pseudonyms names were used for each learner, teacher, and school. Ethical clearance, as defined by Cohen, Manion and Morrison (2000), was approved by the Faculty of Education Ethics committee, as well as by the Department of Education, the schools, teachers and parents.

\section{FINDINGS}

\section{Biographical information}

The six teachers' ages ranged between 25-49 years, and the majority of the teachers (5) were female. The learners' ages ranged between 15-20 years, and the majority of the learners $(61 \%)$ were female.

\section{The inclinations of the learners and teachers regarding animal organ dissection in} general

\section{Responses from the learners}

It appears that the learners were generally inclined towards animal organ dissection. Ninety-three percent $(93 \%)$ of the learners indicated that they enjoyed animal organ dissection because they were interested in experiencing, first-hand, the anatomy of the organ that they were studying. Just over $80 \%$ of the learners felt comfortable with carrying out animal organ dissection themselves, while $20 \%$ were not comfortable with the same idea. The same learners who had reservations in performing animal organ dissection rather opted to use alternatives like online or artificial animal organ dissection, especially in the schools that were technologically equipped to do so, while some of the learners from the financially disadvantaged schools rather watched others dissect the organs. The learners that expressed preferences for alternative dissection also expressed that they found it emotionally difficult to dissect fresh animal organs and they also found animal organ dissection disgusting. Many learners (75\%) did not express any disgust, nor were they emotionally affected by dissecting fresh animal organs. However, $23 \%$ of 
the learners expressed a negative inclination towards animal organ dissection for different reasons, ranging from being emotionally affected to being disgusted, and $75 \%$ of them showed a positive inclination and a lot of interest towards animal organ dissection. However, almost $80 \%$ of the learners were of the opinion that animal organ dissection increased their respect for animals. In terms of their moral values, 186 learners responded that they were in support of animal organ dissection. The learners were allowed to give multiple responses, which were then classified into eight categories (see Table 1). The data $(n=343)$ are expressed in terms of the frequencies and percentages.

Table 1

Moral views of learners supporting animal organ dissection

\begin{tabular}{lcc}
\hline \multicolumn{1}{c}{ Categories elicited from the responses of learners } & $\begin{array}{c}\text { Responses } \\
(n=343)\end{array}$ & $\begin{array}{c}\text { Percentage } \\
\%\end{array}$ \\
\hline $\begin{array}{l}\text { Promote more learning and understanding of animal organ } \\
\text { morphology }\end{array}$ & 120 & 35.00 \\
\hline Links knowledge taught from textbooks with the real organs & 54 & 15.74 \\
\hline Motivation in terms of career choice & 40 & 11.66 \\
\hline Helps get hands-on experience & 30 & 8.75 \\
\hline Improves investigative and practical skills & 29 & 8.45 \\
\hline Textbooks or artificial organs restrict/limit information & 21 & 6.12 \\
\hline Makes studying the topic more interesting & 21 & 6.12 \\
\hline $\begin{array}{l}\text { Organs are obtained from dead animals so this is not cruelty to } \\
\text { animals. It is not murder because it is for a good cause }\end{array}$ & 28 & 8.16 \\
\hline
\end{tabular}

One learner [Learner 154] who was in favour of animal organ dissection claimed that:

The organ helped me to see the parts of the organ which I will always remember them forever, even during exam time because I have seen them than only studying about them looking at the textbook. It also helped understand the function of it and why we should take care of them, while they still function well in our bodies.

Only 45 learners were against animal organ dissection, while nine learners were listed as missing values. Table 2 shows the reasons why these learners were against animal organ dissection, which were classified into six categories.

Table 2

Moral views of learners against animal organ dissection

\begin{tabular}{lcc}
\hline Categories elicited from the responses of learners & Responses & $(n=46$, Percentage $\%$ \\
\hline Against religion or beliefs to dissect animal organs & 11 & 23.91 \\
\hline Cruel to the animal & 10 & 21.74 \\
\hline Many animals had to die for the purpose of dissection & 9 & 19.57 \\
\hline Animals should only be used as a food source & 6 & 13.04 \\
\hline Being vegetarian & 5 & 10.87 \\
\hline Strong respect for animals & 5 & 10.87 \\
\hline
\end{tabular}


One learner [L174] who was against animal organ dissection was quoted as saying:

The only reason why I think we should be cutting up animals is for the sole purpose of our protein. I feel the amount of animals that had to die so that we can just look at their kidney and throw it away is a waste.

It was interesting to note that the majority of the responses (almost $35 \%$ ) indicated that the learners found animal organ dissection exciting, enjoyable, fascinating, amazing, and explained that it aroused their curiosity, and motivated them to see the organ parts on the real tissue. However, a few other learners expressed their disgust regarding the idea of dissecting fresh organs (see Table 3 ).

Table 3

Learners' feelings when carrying out animal organ dissection

\begin{tabular}{lcc}
\hline Categories elicited from the responses of learners & $\begin{array}{c}\text { Responses } \\
(n=352)\end{array}$ & Percentage \% \\
\hline $\begin{array}{l}\text { Exciting, enjoyable, fascinating, amazed, curious and } \\
\text { motivated to see the organ parts on the real tissue }\end{array}$ & 123 & 34.94 \\
\hline $\begin{array}{l}\text { Life Sciences is not just theory but real, practical and } \\
\text { broadens knowledge }\end{array}$ & 60 & 17.05 \\
\hline It was smelly, gross and nauseating & 44 & 12.50 \\
\hline $\begin{array}{l}\text { Felt guilty, cruel and disrespectful towards the dead } \\
\text { animals }\end{array}$ & 38 & 10.80 \\
\hline Felt like a doctor or real life scientist & 30 & 8.52 \\
\hline $\begin{array}{l}\text { Respectful of the animal from which the organ came } \\
\text { because it died for learners' benefit }\end{array}$ & 25 & 7.10 \\
\hline Nervous and scared to cut wrongly and damage the organ & 21 & 5.97 \\
\hline Prefer watching others carry out the dissection & 11 & 3.12 \\
\hline
\end{tabular}

Comments from the teachers

Teachers' inclinations towards animal organ dissection were drawn from the interview questions, which asked them to recall (Rcc) how they felt (F) about animal organ dissection when they carried it out for the first time, and how they felt when they carried it out with their learners. They were also asked if there were occasions (Occ) when they did not feel like participating in the dissection when their learners were dissecting (see Table 4). The teachers were given pseudonyms and codes: Thato (T1 for School A), Mark (T2 for School A), Yvonne (T3 for School B), Bertha (T4 for School B), Mary (T5 for School C) and Tia (T6 for School D). 
Table 4:

Teachers' inclinations towards animal organ dissection

\begin{tabular}{|c|c|c|c|}
\hline Categories & Codes & Teachers' codes & Frequency \\
\hline Scared, blood phobia & Rc1 & T1, T4 & 2 \\
\hline Felt like I had no choice, it was for marks & $\mathrm{Rc} 2$ & T1 & 1 \\
\hline Very interesting, fun, worth it & $\mathrm{Rc} 3$ & $\mathrm{~T} 2, \mathrm{~T} 3, \mathrm{~T} 4, \mathrm{~T} 5, \mathrm{~T} 6$ & 5 \\
\hline $\begin{array}{l}\text { Yes, very new, explored and learnt together } \\
\text { with the learners }\end{array}$ & Rcc1 & $\mathrm{T} 4$ & 1 \\
\hline Not bad & F1 & T1, T3, T4 & 3 \\
\hline Understand their fear & $\mathrm{F} 2$ & $\mathrm{~T} 1, \mathrm{~T} 4$ & 2 \\
\hline The preparation is too involving & F3 & T5 & 1 \\
\hline Gratified by their excitement and experience & F4 & $\mathrm{T} 1, \mathrm{~T} 2, \mathrm{~T} 3, \mathrm{~T} 4, \mathrm{~T} 5, \mathrm{~T} 6$ & 6 \\
\hline No, I always demonstrate & Occ1 & $\mathrm{T} 1, \mathrm{~T} 2, \mathrm{~T} 5$ & 3 \\
\hline Always enjoy dissection & Occ2 & $\mathrm{T} 2, \mathrm{~T} 3, \mathrm{~T} 5, \mathrm{~T} 6$ & 4 \\
\hline $\begin{array}{l}\text { I force myself for the sake of learners' } \\
\text { marks }\end{array}$ & Occ3 & $\mathrm{T} 4$ & 1 \\
\hline
\end{tabular}

Responses codes: $\mathrm{Rc}=$ Recall the feelings; Rcc $=$ Recall; $\mathrm{F}=$ Feeling; Occ $=$ Occasions; $\mathrm{T}=$ Teacher

Thato (T1) (pseudonym) admitted that when she first carried out dissection, she was really scared and could not get herself to dissect the frog that she was supposed to dissect. She knew, however, that she had no choice because of the examination that she had to write. She understood the fear of the learners because she experienced it too and was still trying to overcome the fear and squeamishness at the time of this study. Bertha (T4) (pseudonym) only carried out her first dissection when she was a teacher, and thus explored and learnt together with the learners, but was still fighting her blood phobia at the time of this study. She confirmed this by saying:

It was scary and very exciting to actually think that I was working with something that was inside me and to see how it really looks and the size of it. But I am someone that is not very keen on touching organs with blood, so there was a little bit of a knot in my tummy, I didn't and still don't like it so much.

Bertha's response did not come as a surprise because the researchers had noticed her detachment from the animal organ dissection as the learners were carrying it out. Dissecting for the first time for Mark (T2), Yvonne (T3), Mary (T5) and Tia (T6) (all pseudonyms) were very interesting, fun and they felt that it was worth it. Tia felt that it was too demanding to organise the organs, prepare for the lesson and conduct the dissection lesson itself. Despite her reservations, Tia still enjoyed dissection and even demonstrated whole animal dissection. All six teachers acknowledged that they were always gratified by their learners' excitement and experience. Mark was quoted saying:

I remember way back in college, we did dissection on many organs like the alimentary canal of a rat you remember? It was very much interesting for me and fun... never had any problem with that ... still find it interesting when my learners dissect, it is in me already. I only look at how learners react and if they react positively and seem to have learnt something, that makes my day. 
The majority of the teachers who participated in this study were positively inclined towards animal organ dissection.

\section{Classroom observations}

In Bertha's class, the researcher noticed from the beginning of the lesson how the teacher was seemingly detached from the lesson. For instance, Bertha did not explain or demonstrate the dissection; she simply told them to follow the worksheet instructions. Some learners had started mishandling and pricking the organ without any guidance from her. She was seated at her desk marking, and just shouted at the learners, demanding that they keep quiet and discuss quietly. Her learners moved between groups, some fiddled with dissection instruments, mutilating the organ, and some were on their cell phones or taking photos of each other instead of following the worksheet and completing the dissection task and activities. Some learners were disgusted by the organ's squishiness and fresh blood, but so was the teacher so they had no one to assist them. The researchers had thought that the teacher's detachment was due to a lack of confidence in the animal organ dissection procedure since she did not have a firm previous experience with it. However, during the interview, they also realised that besides her lack of experience, Bertha had a fear of blood.

Thato showed a bit of hesitation at the beginning of the lesson, especially when it came to the demonstration of animal organ dissection. She also only gave the learners the worksheet and instructed them to work quietly as she was busy marking seated at her desk. The learners in her class also did not focus on the dissection, some of them even refusing to dissect giving different excuses. She was unable to persuade them to participate, and was, herself, not willing to actively participate. Contrary to these two teachers, the other four teachers showed a great deal of interest in the animal organ dissection. At the beginning of the lesson, they explained the activity and demonstrated the dissection step by step. Their learners were highly motivated, admittedly, there were some that were against the fresh animal organ dissection for varied reasons. In these cases, the teachers encouraged them to watch their group members dissect, and, depending on the resources, some were watching the virtual dissection on their cellphones.

Inclinations of the learners and teachers towards the use of animal organ dissection in problem-solving

Responses of the learners

From the results, it appeared that the learners generally had positive inclinations towards animal organ dissection and its use in problem-solving. The majority of the learners (98\%) acknowledged that animal organ dissection helped them to improve their investigative skills. More than $80 \%$ of the learners did not only acknowledge the usefulness of animal organ dissection in terms of developing investigative, manipulative skills, but problem-solving skills as well. Just over two-thirds (64\%) of the learners were of the opinion that dissections are the only way to develop manipulative skills. The majority of the learners showed a positive inclination towards using animal organ dissection to improve important skills like problem-solving, investigation, and manipulation, which was very encouraging. 


\section{Comments from the teachers}

The participating teachers were asked two questions. The first was to determine if the teachers thought the dissection of organs were important in problem-solving and the second to discover whether they thought animal organ dissection had any contribution to the development of the problem-solving skills of Grade 11 Life Sciences learners.

Table 5

Teachers' inclinations towards the use of animal organ dissection in problem- solving

\begin{tabular}{lllc}
\hline Categories & Codes & Teachers' codes & Frequency \\
\hline $\begin{array}{l}\text { Yes, it provides clear understanding of } \\
\text { kidney and how to solve problems } \\
\text { associated with its structure and function. }\end{array}$ & Imp1 & T1, T3, T5, T6 & 4 \\
$\begin{array}{l}\text { Yes, seeing the real organ and its parts can } \\
\text { make learners think from a different angle } \\
\text { and solve presented problems in a better } \\
\text { way, and it improves their complex skills. }\end{array}$ & Imp2 & T4, T6 & 2 \\
$\begin{array}{l}\text { Yes it is, learners develop listening, } \\
\text { observation and cooperative skills. }\end{array}$ & & & 1 \\
\hline $\begin{array}{l}\text { It does, especially for those aspiring to } \\
\text { pursue a medical or Life Sciences career. }\end{array}$ & Contr1 & T1, T6 & 2 \\
$\begin{array}{l}\text { They can apply the same knowledge to } \\
\text { other organs or how to investigate them } \\
\text { the same way as with the kidney. }\end{array}$ & Contr2 & T1, T2, T3, T4, T5, T6 & 6 \\
$\begin{array}{l}\text { It does because they did much better in the } \\
\text { post-test than before they dissected. }\end{array}$ & Contr3 & T2, T5 & 2 \\
\hline
\end{tabular}

Responses codes: Imp = Importance Contr = Contribution

Table 5 shows that the teachers concurred that animal organ dissection was important to problem-solving as learners gain a clear understanding of the kidney structure. They were then able to understand the problems associated with its structure and function, as well as how to solve them. The teachers realized that seeing the real organ and its parts could give learners a different perspective and assist them to solve problems better than by only applying theoretical knowledge. One teacher (Bertha) was quoted as saying:

Well, as I believe that if they can see the real life thing they will think of it further on how something like an organ works. And they will think in a different angle, if they see how it actually looks and what implications it can have when you have a problem like a puncture in the lung, or a blockage in the urethra, that they will be able to solve their problems better and think about solutions maybe.

Most of the teachers thought that animal organ dissection made a great contribution to those learners who aspired to entering a medical or Life Sciences career. All six teachers concurred that learners could apply the same knowledge to other organs.

\section{DISCUSSION}

The experiences of South African teachers and learners in terms of animal organ dissection and their inclinations in this regard may relate to the experiences of many 
teachers and learners internationally (Balcombe, 1997; Donaldson \& Downie, 2007; Lord \& Moses 1994).

\section{The learners' inclinations towards animal organ dissection and problem-solving}

The majority $(90 \%)$ of the learners showed a positive inclination towards animal organ dissection as it would help them as life scientists. Similar experiences are shared by De Villiers and Sommerville (2005). However, some of them were not so keen to carry out the hands-on dissection of the fresh organs themselves.

More than a quarter $(26 \%)$ of the learners had a negative inclination towards animal organ dissection in problem-solving because the idea of being tested after carrying out animal organ dissection was not appealing to them. The reasons for this inclination may be ascribed to a lack of sufficient engagement with animal organ dissection, and hence they were not prepared to answer the challenging questions. According to the teachers, some of the learners had a negative inclination towards animal organ dissection thinking that it was just an activity of cutting and drawing. When they were presented with the challenging questions, they were motivated to explore the dissected kidney further. According to the teachers, some of their learners were more interested in just cutting and drawing, which is referred to as a traditional dissection. When the time came for them to answer the problem-solving questions, they were less enthusiastic. The inclination of learners is also noted in the literature (Aaronsohn, 2003) as learners tend to be resistant to new instructional methods because they are more comfortable in their routine or old method of instruction. In other words, the amount of work might have scared them off.

The learners who struggled more with the given problem-solving activities experienced this mainly due to a lack of support from their teachers. This shows that teachers' inclination towards animal dissection has an impact on the outcome of the lesson and the inclinations of their learners towards animal organ dissection and its use in problemsolving. This is supported by Gbore and Daramola (2013), who state that a learner may form an attitude towards learning certain topics and certain activities based on the teacher's, family's and peer group's disposition, which could positively or negatively affect their inclinations, and possibly their performance in the topic or activity. Hart et al. (2008) also add that it seems likely that the choice of the teacher's use of certain teaching methods is influenced by their related experiences and knowledge. If learners are negatively influenced, they may start tertiary education unprepared and without basic dissection skills, which may contribute to a lack of conceptualisation.

\section{The teachers' inclinations towards animal organ dissection and problem-solving}

It could be argued that some teachers may have had a negative inclination due to a lack of confidence in carrying out dissections on fresh animal organs. This was evidenced by the lack of enthusiasm towards animal organ dissection of teacher Bertha, who had not had any hands-on dissection experience in her schooling and, as a result, let her learners work without her assistance. Such teachers do not actively assume their roles of guiding their learners during the activity to avoid exposing their inexperience in the dissection of animal organs. The minimal supervision in Bertha and Thato's classes due to the teachers' blood phobia, squeamishness, and lack of confidence was evident in the 
learners' misbehaviour, as stated in the findings. Yavuzer (2000) affirms that the principles of teaching abilities include teachers supporting their students, and demonstrating their positive expectations in order to motivate the students to learn. Gresham (2008) is of the opinion that if a teacher is uncomfortable with a subject or doubts their ability to implement reform-based practice, they may focus less time on it or reveal their negative feelings to their learners, which was evidenced by Bertha's attitude.

Even though some teachers are negatively inclined towards animal organ dissection due to blood phobia, a lack of dissection skills and a lack of apparatus; all of them were positively inclined towards the use of animal organ dissection and acknowledged that it was significant in problem-solving. With this inclination, there is hope that teachers may nevertheless use animal organ dissection to improve their teaching strategies.

\section{RECOMMENDATIONS}

If teachers hope for their learners to adopt a positive inclination towards animal organ dissection, then they too need to demonstrate such a stance as a way of encouraging their learners. Staff development programmes, such as animal organ dissection workshops, will help to boost Life Sciences teachers' confidence in acquiring the necessary dissection skills. They are encouraged to allow the learners with a blood phobia to use alternative methods, such as artificial animal organ dissection (3D models) and the virtual simulation of animal organ dissection in order to promote a positive inclination towards dissection, as recommended by Oakley (2012). It is also recommended that the dissection of both fresh and artificial animal organs be designed around problem-solving activities more specifically.

\section{CONCLUSION}

The findings show that the inclinations of the learners towards animal organ dissection were predominantly positive. Less than a quarter of the whole group was negative due to a variety of factors, which included moral values, religion, culture, a blood phobia, squeamishness, and being vegetarian. The researcher also observed that the abovementioned problems were real, and for some learners, it was so bad that they could not stand the sight of blood, let alone touch the organ. The majority of the learners believed in the importance of animal organ dissection in developing skills like investigative, dissecting, and problem-solving skills. This belief resulted in them being positive towards the use of animal organ dissection in problem-solving. The teachers confirmed in the interviews that the inclinations of the learners during the hands-on dissections were very positive.

The responses of the teachers further revealed that a third of them still had reservations about animal organ dissection, especially because of being afraid of blood. Thus, they understood why their learners feared touching the organs. It was also established that in some cases, the negative inclination towards animal organ dissection was not only attributed to the teachers being blood phobic, but also due to a low confidence level in dissection skills. In Bertha's case specifically, she was therefore less inclined to dissect animal organs with her learners. Even though a third of the teachers had negative 
inclinations towards hands-on dissection, it was noted that all six teachers acknowledged that animal organ dissection is of vital importance in the development of skills like enquiry, investigative, practical and problem-solving skills. After the whole exercise, the participating teachers were already considering using the dissection of animal organs to improve their teaching strategies in problem-solving.

This study was conducted at four secondary schools in one province in South Africa only. Because of the small sample size that applied to both the quantitative and qualitative sections of the investigation, it would be very difficult to generalise the findings to a broader population. However, the findings are valid in terms of the opinions of the teachers and learners who participated in the study, and provide us with some understanding of factors that could influence learners' inclinations towards the use of animal organ dissections as part of problem solving.

\section{NOTES}

1. Learners: individuals studying at schools.

2. Students: individuals studying at a tertiary education institution.

3. Township: predominantly black, highly populated residential area.

\section{REFERENCES}

Aaronsohn, E. (2003). The exceptional teacher: Transforming traditional teaching through thoughtful practice. San Francisco: Jossey-Bass.

Al-Tamimi, S.A.M. (2015). Measuring inclinations and attitudes of university teachers towards sports activities. Journal of Sports Science, 3, 44-48.

Balcombe, J.P. (1997). Student/teacher conflict regarding animal dissection. The American Biology Teacher, 59(1), 22-25.

Balcombe, J.P. (2000). The use of animals in education. Problems, alternatives, and recommendations. Washington, DC: Humane Society Press.

Cohen, L., Manion, L., \& Morrison, K. (2000). Research methods in education ( $5^{\text {th }}$ edition). London and New York: Routledge.

Creswell, J.W. (2009). Research design: Qualitative, quantitative, and mixed methods approaches ( $3^{\text {rd }}$ edition). California: Sage.

De Villiers, J.J.R., \& Sommerville, J. (2005). Prospective biology teachers' attitudes toward animal dissection: Implications and recommendations for the teaching of biology. South African Journal of Education, 4, 247-252.

Donaldson, L., \& Downie, R. (2007). Attitudes to the uses of animals in education: Has anything changed? Bioscience Education. Retrieved 16 November, 2015 from www.bioscience.heacademy.ac.uk/journal/vol10/beej-10-6.pdf.d16

Downie, J.R., \& Alexander, L. (1989). The use of animals in biology teaching in education. Journal of Biological Education, 23(2), 103-111.

Garrison, D.R. (2007). Online community of inquiry review: Social, Cognitive, and Teaching Presence Issues. Journal of Asynchronous Learning Networks, 11(1), 61-72. 
Gay, L.R., \& Airasian, P.W. (2000). Educational research: Competencies for analysis and application. (6th edition). Merrill/Prentice Hall.

Gbore, L.O., \& Daramola, C.A. (2013). Relative contributions of selected teachers' variables and students' attitude toward academic achievement in Biology among senior secondary school students in Ondo State. Current Issues in Education, 16(1), 1-11.

Gresham, G. (2008). Mathematics anxiety and Mathematics teacher efficacy in elementary pre-service teachers. Teacher Education 19, 171-184.

Hart, L.A., Wood, M.W., \& Hart, B.L. (2008). Why dissection? Animal use in education. London: Greenwood Press.

King, L.A., Ross, C.L., Stephens, M.L., \& Rowan, A.N. (2004). Biology teachers' attitudes to dissection and alternatives. Alternatives to Laboratory Animals, 32(1), 475-484.

Lord, T.R., \& Moses, R. (1994). College students' opinions about animal dissection. Journal of College Science Teaching, 23(5), 267-270.

McCain, T. (2005). Teaching for tomorrow: Teaching content and problem-solving skills. California: Sage.

Millett, K., \& Lock, R. (1992). GCSE learners' attitudes towards animal use: Some implications for biology/science teachers. Journal of Biological Education, 26(3), 204-208.

Mohamed, L., \& Waheed, H. (2011). Secondary students' attitude towards mathematics in a selected school of Maldives. International Journal of Humanities and Social Science, 15, 277-278.

Moore, R. (2001). Why I support dissection in science education. Journal of Applied Animal Welfare Science, 4(2), 135-138.

Morton, D.B. (1987). Animal use in education and the alternatives. Alternatives to Laboratory Animals, 14, 334-343.

Oakley, J. (2012). Dissection and choice in the Science classroom: Student experiences, teacher responses, and a critical analysis of the right to refuse. Journal of Teaching and Learning, 8(2), 15-29.

Osama, K.R. (2000). Physics psychological. Cairo: Dar Al-Fiker Al-Arabi Company for Publishing.

Reiss, M.J., \& Beaney, N. (1992). The use of living organisms in secondary school science. Journal of Biological Education, 26, 63-66.

Smith, W. (1994). Use of animals and animal organs in schools: Practice and attitudes of teachers. Journal of Biological Education, 28,111-118.

Stannistreet, M., Spofforth, N., \& Williams, T. (1993). Attitudes of children to the uses of animals. International Journal of Science Education, 15, 411-425.

Strauss, R.T., \& Kinzie, M.B. (1994). Student achievement and attitudes in a pilot study comparing an interactive videodisc simulation to conventional dissection. The American Biology Teacher, 56 (7), 398-402.

Yavuzer, H. (2000). School age child. Istanbul: Remzi. 


\section{Turkish Abstract \\ Öğretmenlerin ve Öğrencilerin Hayvan Organlarının Teşrihi ve Bunu Problem Çözmede Kullanmaya İlişkin Eğilimleri}

19. yüzyılın başlarından beri geleneksel olarak hem ulusal hem de uluslararası Yaşam Bilimi Eğitiminde (Biyoloji), hayvan ve organ morfolojisi araştırmalarında teşrih gelişmiştir $\mathrm{Bu}$ çalışma öğretmenlerin ve öğrenenlerin hayvan organlarının teşrihine ve bunu Güney Afrika, Gauteng Şehrinde 11. sınıf Biyoloji eğitiminde problem çözmede kullanmalarına ilişkin eğilimlerini araştırmıştır. Araştırma karma yöntem ile desenlenmiş olup verilerin toplanmasında 224 öğrenciye anket formu dağıtılmış; ders gözlemlenmiş ve 6 öğretmen ile görüş̧e yapılmıştır. Sonuçlar öğretmenlerin ve öğrencilerin büyük coğunluğunun hayvan organlarının teșrihine karș1 ilgili olduğu, bunun 11. sınıf biyoloji programındaki spesifik problemlerin çözümünde değer katan bir kullanımı olduğuna inandıklarını göstermiştir. Birkaç öğretmen hayvanların organ teşrihiyle ve öğrencilerinin bu yöntemi problem çözmede kullanmalarına izin vermeye istekli olmadıklarını belirtmişlerdir.

Anahtar Kelimeler: biyoloji, teşrih, eğilim, öğrenci, Yaşam Bilimi, problem-çözme, öğretmenler

\section{French Abstract}

Les inclinations de Professeurs et Apprenants vers Dissection d'Organe Animale et Son Utilisation dans Résolution de problems

À Life Sciences l'enseignement, tant nationalement qu'internationalement, l'étude d'animal et la morphologie d'organe a traditionnellement impliqué la dissection depuis le premier 19ème siècle. Cette étude s'est concentrée sur les inclinations de professeurs et des apprenants vers la dissection d'organe animale et son utilisation dans la résolution de problèmes dans la Catégorie 11 enseignement de Life Sciences dans la Province(le Domaine) Gauteng, l'Afrique du Sud. Un design de recherche de méthodes mixte a été utilisé pour rassembler des données de 224 apprenants avec un questionnaire, suivi par des observations de leçon et des entretiens(interviews) avec six professeurs. Les résultats montrent que la majorité des professeurs et des apprenants avait le grand(super) intérêt dans des dissections d'organe animales performantes, croyant que son utilisation pourrait ajouter la valeur à la résolution des problèmes spécifiques qui sont relatés(liés) à la Catégorie 11 programme d'études de Life Sciences. Quelques professeurs ne tenaient pas à la dissection d'organe animale et étaient réticents à laisser leurs apprenants disséquer et l'utiliser dans la résolution de problèmes.

Mots Clés: biologie, dissection, inclinations, apprenants, Life Sciences, résolution de problèmes, professeurs

\section{Arabic Abstract}

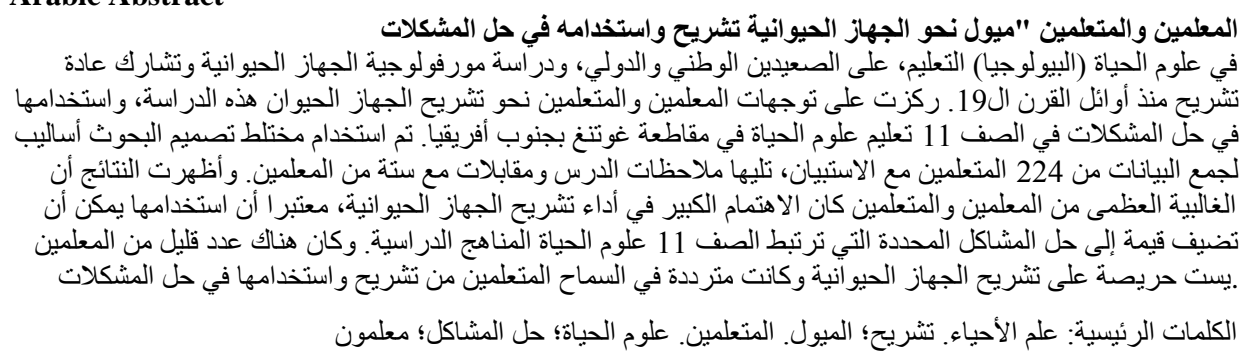

German Abstract

Die Neigung der Lehrer und der Lernenden zur Tierorgan-Dissektion und deren Verwendung bei der Problemlösung

In der Biowissenschaften (Biologie), sowohl national als auch international, hat das Studium der Tierund Orgelmorphologie traditionell die Sektion seit dem frühen 19. Jahrhundert beteiligt.Diese Studie 
konzentrierte sich auf die Neigungen von Lehrern und Lernenden zur Tierorgandissektion und deren Verwendung in der Problemlösung in der Ausbildung der Erziehungswissenschaften in der GautengProvinz, Südafrika. Ein gemischtes Methodenforschungsdesign wurde verwendet, um Daten von 224 Lernenden mit einem Fragebogen zu sammeln, gefolgt von Unterrichtsbeobachtungen und Interviews mit sechs Lehrern. Die Ergebnisse zeigen, dass die Mehrheit der Lehrer und Lernenden großes Interesse an der Durchführung von tierischen Orgel-Dissektionen hatte und glaubte, dass ihre Verwendung einen Mehrwert für die Lösung von spezifischen Problemen schaffen könnte, die mit dem Grade 11 Biowissenschaftscurriculum zusammenhängen. Ein paar Lehrer waren nicht scharf auf Tierorgandissektion und zögerten, ihre Lernenden zu sezieren und sie bei der Problemlösung zu benutzen.

Schlüsselwörter: biologie, preparation, neigungen, lernenden, biowissenschaften, probleme lösen, lehrer

\section{Malaysian Abstract \\ Guru-Guru dan Pelajar kecenderungan ke arah Pembedahan Organ Haiwan dan Penggunaannya dalam Penyelesaian masalah}

Dalam Sains Hayat Pendidikan (Biologi) di peringkat nasional dan antarabangsa, kajian haiwan dan morfologi organ secara tradisinya melibatkan pembedahan sejak awal abad ke-19. Kajian ini memberi tumpuan kepada kecenderungan guru-guru dan pelajar ke arah pembedahan organ haiwan, dan penggunaannya dalam penyelesaian masalah di Gred 11 pendidikan Sains Hayat di Wilayah Gauteng, Afrika Selatan. Reka bentuk kaedah penyelidikan campuran telah digunakan untuk mengumpul data daripada 224 pelajar dengan soal selidik, diikuti dengan pemerhatian pengajaran dan temu bual dengan enam guru. Hasil kajian menunjukkan bahawa majoriti guru-guru dan pelajar mempunyai minat yang besar dalam melaksanakan pembedahan organ haiwan, mempercayai bahawa penggunaannya boleh menambah nilai kepada penyelesaian masalah yang tertentu yang berkaitan dengan Gred 11 kurikulum Sains Hayat. Beberapa guru tidak berminat untuk pembedahan organ haiwan dan enggan untuk membenarkan pelajar mereka membedah dan menggunakannya dalam menyelesaikan masalah.

Kata Kunci: biologi, pembedahan, kecenderungan, pelajar, Kehidupan Sains, penyelesaian masalah, guru

\section{Russian Abstract}

Учителея и Учащихся Наклоны в Сторону Животные Органные Рассечение и Ее Использование в Решении Проблем

Наука о жизни (биология), как на национальном, так и на международном уровне, изучает животных и морфологию органов с помощью препарирования с раннего 19-го века. Эта учеба сосредоточена на заинтересованности учителей и учащихся 11 классов к препарированию животных и их органов. Для использования полученного опыта в решении проблем в области образования в провинции Гаутенг, Южная Африка. В области образования использовали “Смешанный дизайн-метод” исследования для сбора данных от 224 учащихся, с последующим уроком наблюдения и интервью с шестью учителями. Результаты показывают, что большинство учителей и учеников имели большой интерес в выполнении препарирования органов животных, полагая что использование этого опыта может помочь в решении конкретных проблем, которые связаны с изучением биологии в 11-ом классе. Часть учителей выразили негативное отношение к методу препарирования. Они не хотят, чтобы их ученики использовали этот метод в решении проблем биологии.

Ключевые Слова: биология, рассечение, наклонности, учащихся, науки о жизни, решение проблем, учителея 